\title{
Kejadian Hipertensi dengan Gaya Hidup dan Pola Makan
}

\author{
Galuh Dewi Kusumawardani \\ Insitut Ilmu Kesehatan Surya Mitra Husada \\ galuhdewiwrdn@gmail.com
}

\begin{abstract}
ABSTRAK
Hipertensi atau tekanan darah tinggi adalah kondisi saat tekanan darah berada pada nilai 130/80 mmHg atau lebih. Kementerian Kesehatan Republik Indonesia mengatakan bahwa hipertensi saat ini sudah menjadi masalah dunia, termasuk di Indonesia. Direktur Jenderal Pencegahan dan Pengendalian Penyakit Kemenkes Anung Sugihantono merujuk data World Health Organization (WHO) yang menyatakan terdapat 1 miliar kasus hipertensi di seluruh dunia. Sedangkan di Indonesia menurut catatan data Kemenkes pada 2016, terdapat 63.309 .620 kasus dan kematian sebanyak 427 ribu. Berdasarkan Riskedas tahun 2018 di Indonesia tercatat 8,4\% penduduknya terdiagnosis hipertensi. ada beberapa faktor yang dapat meningkatkan risiko seseorang mengalami tekanan darah tinggi, salah satunya adalah dari gaya hidup dan pola makan. Pola kebiasaan buruk seperti merkok menjadi pemicunya. Demikian pula dengan pola makan yang kurang sehat dapat menyebabkan hipertensi.
\end{abstract}

\section{LATAR BELAKANG}

Hipertensi adalah peningkatan tekanan darah sistolik lebih dari $140 \mathrm{mmHg}$ dan tekanan darah diastolik lebih dari $90 \mathrm{mmHg}$ pada dua kali pengukuran dengan selang waktu lima menit dalam keadaan cukup istirahat/tenang (Kemenkes RI, 2013). Penyakit tekanan darah tinggi atau hipertensi telah membunuh 9,4 juta warga dunia setiap tahunnya. Badan Kesehatan Dunia (WHO) Angka memperkirakan, jumlah penderita hipertensi akan terus meningkat seiring dengan jumlah penduduk yang membesar. Pada 2025 mendatang, diproyeksikan sekitar 29 persen warga dunia terkena hipertensi.(Kompas.com,2013).

Berdasarkan Riskedas tahun 2018 di Indonesia tercatat 8,4\% penduduknya terdiagnosis hipertensi dengan Sulawesi Utara tercatat peringkat tertinggi penduduknya yang terdiagnosis 
hipertensi yaitu 13,5\%. Banyak faktor risiko yang menimbulkan hipertensi diantaranya kebiasaan atau gaya hidup seperti merokok, minum alkohol, makanan berlemak. Merokok merupakan salah satu kebiasaan yang lazim ditemui dalam kehidupan seharihari. Hal ini bisa kita lihat dari banyaknya orang-orang yang merokok baik di tempat umum, kantor maupun sekolah-sekolah. Akibat negatif dari rokok sesungguhnya sudah mulai terasa pada orang yang baru menghisap rokok. Mengisap satu batang rokok, nikotin yang terkandung dalam asap rokok semuanya terserap oleh tubuh, kadar dalam darah dapat mencapai 40-50 mg/ml. Nikotin merangsang sekresi hormon adrenalin yang bersifat memacu jantung bekerja lebih berat, sehingga tekanan darah meningkat.

Salah satu faktor penyebab hipertensi adalah kebiasaan pola hidup yang kurang baik dan pola makan yang kurang sehat.

\section{KASUS/MASALAH}

Bagaimana kejadian hipertensi dengan pola kebiasaan dan pola makan?

\section{TINJAUAN PUSTAKA}

Hipertensi adaah keadaan seseorang yang mengalami peningkatan tekanan darah normal diatas normal sehingga mengakibatkan peningkatana angka morbiditas maupun mortalitas, tekanan darah fase sistolik $140 \mathrm{mmHg}$ menunjukan fase darah yang sedang dipompa oleh jantung dan fase diastolik $90 \mathrm{mmHg}$ menunjukan fase darah yang kembali ke jantung (Triyanto,2014).

Hipertensi merupakan penyakit yang mendapat perhatian dari seluruh lapisan masyarakat karena dapat menimbulkan dampak jangka pendek maupun jangka panjang (Ismarina dkk, 2015).

Terdapat banyak faktor yang mempengaruhi tekanan darah pada orang dewasa, diantaranya adalah pola kebiasaan dan pola makan. Gaya hidup merupakan faktor penting yang mempengaruhi kehidupan masyarakat. Gaya hidup yang tidak sehat dapat menjadi penyebab terjadinya hipertensi misalnya aktivitas fisik dan stres (Puspitorini dalam Sount dkk. 2014). Pola makan yang salah merupakan salah satu faktor resiko yang meningkatkan penyakit hipertensi. Faktor makanan modern sebagai penyumbang utama terjadinya hipertensi (AS,2010)

Kelebihan asupan lemak mengakibatkan kadar lemak dalam tubuh meningkat, terutama kolesterol yang menyebabkan kenaikan berat badan sehingga volume darah mengalami 
peningkatan tekanan yang lebih besar (Ramayulis, 2010). Kelebihan asupan natrium akan meningkatkan ekstraseluler menyebabkan volume darah yang berdampak pada timbulnya hipertensi (Sutanto, 2010).

\section{PEMBAHASAN}

Hipertensi merupakan masalah kesehatan besar di seluruh dunia sebab tingginya prevalensi dan berhubungan dengan peningkatan risiko penyakit kardiovaskular (World Health Organization, 2010). Prosentase penderita hipertensi saat ini paling banyak terdapat di negara berkembang. Data Global Status Report on Noncommunicable Disesases 2010 dari WHO menyebutkan, 40 persen negara ekonomi berkembang memiliki penderita hipertensi, sedangkan negara maju hanya 35 persen. Kawasan Afrika memegang posisi puncak penderita hipertensi sebanyak 46 persen. Sementara kawasan Amerika menempati posisi buncit dengan 35 persen. Di kawasan Asia Tenggara, 36 persen orang dewasa menderita hipertensi (Kompas,2013).

Berdasarkan penelitian yang telah dilakukan oleh Mahmudah dkk pada tahun 2105 menyebutkan bahwa ada hubungan yang signifikan antara aktivitas fisik, asupan lemak, dan asupan natrium dengan kejadian hipertensi. Berdasarkan hasil regresi logistik berganda asupan natrium yang paling berhubungan dengan kejadian hipertensi yang memiliki resiko 4,627 kali lebih besar untuk mengalami kejadian hipertensi.

Dalam penelitian yang dilakukan oleh Andamsari dkk pada tahun 2015 menjelaskan Rerata pola konsumsi responden per hari untuk Lemak sebesar 40,29 gram, Kalori 1597,48 kcal, Vitamin C 57,35 mg, dan Kalsium 201,26 mg. Rata rata tekanan darah responden untuk tekanan darah sistolik adalah 128,90 $\mathrm{mmHg}$ (SD 22,02 $\mathrm{mmHg}$ ), tekanan darah diastolik adalah 81,18 mmHg (SD 11,24 $\mathrm{mmHg}$ ) dan 20\% responden tergolong ke dalam hipertensi. Terdapat hubungan yang bermakna antara konsumsi lemak dengan tekanan darah sistolik, namun tidak terdapat hubungan dengan tekanan darah diastolik.

Berdasarkan penelitian yang dilakukan Suoth dkk yang dilakukan pada tahun 2014 menyimpulkan Ada hubungan yang bermakna antara gaya hidup dalam bentuk konsumsi makanan dengan kejadian hipertensi di Puskesmas Kolongan, Kecamatan Kalawat, Kabupaten Minahasa Utara. Ada hubungan yang bermakna antara gaya hidup dalam bentuk kemampuan mengatur stres dengan kejadian hipertensi di Puskesmas Kolongan, Kecamatan Kalawat, 
Kabupaten Minahasa Utara. Tidak ada hubungan yang bermakna antara gaya hidup dalam bentuk kebiasaan merokok dengan kejadian hipertensi di Puskesmas Kolongan, Kecamatan Kalawat, Kabupaten Minahasa Utara.

\section{KESIMPULAN}

Dari berbagai jurnal dan teori diatas dapat ditarik kesimpilan bahwa gaya hidup dan pola makan berpengaruh terhadap kejadian hipertensi.

\section{DAFTAR PUSTAKA}

Andamsari, Nur, dkk. 2015. Hubungan Pola Makan Dengan Tekanan Darah Pada Orang Dewasa Di Sumatera Barat. MKA Volume 38, Nomor 1, Jan-April 2015. Diakses dari http://jurnalmka.fk.unand.ac.id

AS,M.2010, Hidup bersama hipertensi.Yogyakarta:In book

Badan Penelitian dan Pengembangan Kesehatan Kementrian RI.2019. Laporan Nasional Riskesdas 2018. Jakarta: Lembaga Penerbit Balitbangkes.

Ismarina, Herliawati. Dkk. 2015. Perbandingan Perubahan Tekanan Darah Lansia Penderita Hipertensi Setelah dilakukan Terapi Musik Klasik dan Relaksasi Autogenik di Wilayah Kerja Puskesmas Palembang

Kompas.com. 2013. Penderita Hipertensi Terus Meningkat. https://lifestyle.kompas.com/read/2013/04/05/1404008/Penderita.Hipertensi.Terus.Meningk at. Diakses 4 Januari 2020

Mahmudah, Solehatul, dkk. 2015. Hubungan Gaya Hidup Dan Pola Makan Dengan Kejadian Hipertensi Pada Lansia Di Kelurahan Sawangan Baru Kota Depok. Diakses dari http://jurnal.ums,ac,id

Prasetyaningrum, YI. 2014.Hipertensi bukan untuk ditakuti.Jakart: Fmedia Imprint AgroMedia Pustaka

Ramayulis, R. 2010. Menu dan resep untuk penderita hipertensi. Jakarta:Penebar Plus 
Suoth, M, Bidjuni, H, Malara, RT 2014 'Hubungan gaya hidup dengan kejadian hipertensi di puskesmas kolongan kecamatan kaawat kabupaten minahasa utara 2014', Jurnal Keparawatan (e-Kp), vol.2, no.1, Februari 2014, hlm.1-10. 